\title{
Administrative, Infrastructure and Finance Related Factors Affecting Private Investment in East Gojjam Zone, Ethiopia
}

\author{
Megbaru Tesfaw Molla \\ Department of Accounting and Finance, College of Business and Economics, Debre Markos University, \\ P.O.Box 269, Debre Markos Ethiopia
}

\begin{abstract}
The aims of this study is to examine Administrative, Infrastructure and Finance related factors affecting private investment activities in East Gojjam zone with the intention of providing valuable information about the investment environment of the zone to the potential investors. Descriptive type of research design has been used in this study by giving more emphasis on qualitative data analysis method. The study used bprimary data. Pre-designed selfadministered questionnaire has been used to collect primary data. In order to obtain primary data, a total of 299 questionnaires were distributed to investors found in East Gojjam zone and 294 of them were filled and returned to researchers. The outcome of this study revealed that, the major bottlenecks of investment in East Gojjam zone are Administrative and policy related factors, Infrastructure related factors Macro economic variables which have a nationwide effect, unavailability of foreign exchange reserves and exchange rate fluctuations affects private investment in East Gojjam Zone.
\end{abstract}

Keywords: Administrative Factors, Infrastructure Factors, Finance Factors and Private Investment DOI: $10.7176 /$ RJFA/10-23-02

Publication date: December $31^{\text {st }} 2019$

\section{1 . Background of the study}

According to the report of United Nations Conference on Trade and Development (UNCTAD) (2002), Investment is one of the primary engines of growth in all economies. However, its effectiveness rests on strong complementarities with other elements in the growth process, most notably technological progress, skills acquisition and the development of innovative capability. These elements make investment a natural point of departure for Governments seeking to formulate a robust development strategy. The link between investment and these other determinants of growth, however, is not an automatic process. It requires among other things a favorable macro policy environment and specific policies and institutions aimed at encouraging savings and attracting and directing investment to key sectors in the economy thereby enhancing the contributions of investment to skills formation, technological change, competitiveness and economic growth.

In fact, in the world, there is no smooth development that can be achieved rather than passing through a series and complex stages of activities. Now a day the development of any country is determined by improved investment activity. Without investment activity it is not possible to have any development rather to remain in the circle of poverty. This is especially true in developing countries like Ethiopia.

Investments are gradual, under all prospective change and their change all over the economic development is varying in all countries. In many countries individuals or organizations participate in investments to increase their wealth over time.

The investors invest part of their income for future financial gain, investing to protect the purchasing power of saved money against rising price, to buy their own business such as a store or gas situation and so on.

The marginal benefit from private sector investment has an enormous role in the countries' economic growth and development, and increasing the public sector investment at the expense of the private one might have a deleterious effect on the growth of private sector and retards economic growth of countries, though the total investment as percentage of GDP remain unchanged (Majeed and Khan 2008). In light of this, giving recognition to the development of private sector become recent phenomena. Thus, developing countries' governments give much emphasis and energy to attract private investment believing this will overcome constraints on economic growth through promoting technology transfer, creating employment opportunity and attracting other investors in a more diversified economy. In doing so, developing countries have launched specific concerned bodies to facilitate and provide support to investors (Pfeferman and Madarasy1992).

Ethiopia has showed impressive economic growth and investment inflow in recent years, driven by political stability, the low cost environment and supportive state policies (korolev, 2010).

To speed up the economic and social development of the country, the efficient and effective utilization of these resources are typical. Investment has a great role in the development of an economy. Therefore, improving investment activity in the way in which development is possible for a country under poor nation. So, due attention must be given to the cause of low level investment activities, by identifying and conducting study from time to time on the opportunities and challenges to achieve the desired result which is, sustainable economic development. 
Financing, a qualified labor force and infrastructure remain the key constraints faced by business in Ethiopia. However, these constraints are partly manageable in the short term by bringing own financing, technology and process management to Ethiopia in order to transfer knowledge processes to the local workforce. Infrastructure constraints are not prohibitive in most cases and can be managed through proper site selection.

The improving business climate in Ethiopia provides attractive opportunities for investors capable of bringing financing, technologies and process management as well as creating employment.

\subsection{Statement of the Problem}

According to the report of the Oakland Institute(2010) Ethiopia has created a very attractive investment climate in recent years by providing potential investors with various tax breaks, access to affordable land, a relatively efficient investment process, very affordable land rents, suitable agro-climatic conditions, low labor costs (labor is cheap and abundant), outstanding incentives, including tax holidays and no duty, relaxed regulations, corruption is low relative to other countries, abundant amounts of "undeveloped" land, strategic location (with respect to markets), abundant water resources, ability to export privileged access to other markets, streamlined investment process. In addition, the Ethiopian government has established a "land bank," further facilitating the process through which investors acquire land. Utilizing the advantage of natural resources for export of highvalue agricultural products is the best strategy to achieve rapid economic growth for a country.

The Administrative, Infrastructure and Finance related factors of private investment have been substantially studied by different researchers, (Morisset, and Jacques 2000; Basu and Srinivasan, 2002; Salish, and Mohammed, 2003). These and other researchers investigated their study on this area and identified the Administrative, Infrastructure and Finance related factors in different countries and areas. However, almost all of these studies conducted on developed and large areas. From such findings it is difficult to generalize the same result in East Gojjam zone. As per the researcher knowledge research studies on the Administrative, Infrastructure and Financerelated factors private investment environment in East Gojjam zone remained an ignored area of study. Thus, with these serious shortcomings of the current literature, this study will contribute to the existing literature.

East Gojjam zone is among the zones found in Amhara Region which has attractive natural resource. However, with such ample resources availability and investment potentiality within the zone, the investment activities had been carried out was not sufficient as expected.

By considering the above situations, the researcher was motivated to conduct this study to identify Administrative, Infrastructure and Finance related factors affecting private investment activity in East Gojjam zone and to remind the concerned body about these issues.

\subsection{Objectives of the study}

\subsubsection{General objective}

The general objective of the study is to examine Administrative, Infrastructure and Finance related factors affecting of private investment activities in East Gojjam zone with the intention of providing valuable information about the investment environment of the zone to the potential investors.

\subsubsection{Specific objectives}

In addition to the general objective, the study has the following specific objectives:

1. To identify the Administrative factors affecting of private investment activities.

2. To examine the Infrastructure factors affecting of private investment activities.

3. To investigate Finance related factors affecting of private investment activities.

\subsection{REVIEW OF RELATED LITERATURES}

\subsubsection{Investment Defined}

Investment is the key determinant to economic growth. Investment is the source of manufactured goods that will be used to produce other goods. It is the major foundation of enhancement in the level of literacy, improvement in technology and increase in the capital stock (Hashmi et al 2012). According to Nainnggolanet al.. (2014) investment, which is available through a variety of means of production, is a very important component in the development process that will be optimized to produce the output, thereby increasing economic growth.

Investing activities are carried out in two main forms; the public and the private investment. The public investment is generally carried out in the form of infrastructure development as well as the provision of facilities- both physical and non-physical- that will drive the businesses to sustain the economic activities. On the other hand, private investments in the form of domestic investment and foreign capital are used as an important prerequisite for the economic growth in a country because it allows entrepreneurs to develop their business through empowering economic resources to create goods and services for a better economic growth (Nainggolan.et al..2014). 


\subsubsection{Empirical Literature Review}

\subsubsection{Administrative Factors}

The quality of governance directly affects the level and nature of private investment in a country.

Private investment in turn is a major determinant of economic growth, and the ability of a country to reduce or alleviate poverty and improve the lives of its citizens. The relationship of governance to private investment is complex and is subject to many influences (Emery, 2003).

Emery (2003), in his study entitled with governance, transparency and private investment in Africa, identifies the specific aspects of governance which affect private sector activity, and private investment in particular, which cover a range of interactions between the public and private sector as follows: maintenance of policy distortions which create exceptional opportunities for rent seeking, patronage and pilferage; use of direct government ownership for political and patronage objectives, and the corresponding exclusion of private activity in these sectors; corruption and dysfunction of the judiciary system; corruption in the granting of licenses, permits, etc. corruption or favoritism in the collection of tax revenues from business, including general taxation revenues normally collected by Revenue agencies and trade taxes collected by Customs Authorities; corruption or arbitrary enforcement of business regulations, such as labor, environmental, and other standards

All of these factors are important determinants of the business climate, and feature prominently in competitiveness, or the attractiveness of a country as an investment location. According to Ajide, degree of openness, previous value of inflation rates and governance indicators are the most important factors but political stability and voice and accountability indicators appear to dominate the governance indicators space as they are both negative and significantly affecting the private investment mobilization (Ajide , 2013). Likewise, unpredictable and inefficient investment climate (which could be due to reasons such as frequent changes of investment policies and requirements, inefficient bureaucracy, prolonged poor governance and rampant corruption among others), would deteriorate investors' confidence and appetite (Adugna, 2013)

\subsubsection{Infrastructure factors}

A study made by Awet, et al..(2014) entitled challenges and opportunities of private investment in Tigray region, particularly in manufacturing sector, identified that access to finance, marketing, infrastructures facilities, incentive provision, land provision process and getting required land size, and bureaucracy are some of the major bottlenecks of private investment in that region.

According to the Definition of Organization for Economic Cooperation and Development Annual Report (2006) Infrastructures are public goods and services that go into the production process as complementary inputs for traditional factors of production such as capital, labor and entrepreneur. They help to increase returns on investment by reducing production cost and improving transition efficiency. The availability of infrastructure facilities and services as well as the efficiency of such services to a large extent determine the success or otherwise of all other production endeavor. Investments in infrastructures such as energy, water, transportation and communication technologies promote economic growth and help to alleviate poverty and improve living conditions in developing countries.

Peter (2010) argued that beyond universal services infrastructure, the shifting age structureof the population, particularly the rising number of working-age people, will require countries to provide economic infrastructure that can attract private sector investments and facilitate the creation of jobs. And urbanization, which will require the creation of jobs in urban centers, will also necessitate the availability of infrastructure to exploit the production potential of rural areas in the agricultural and forestry sectors.

A study by Stephen et al, (2014)entitled impact of Government expenditure on private investment in Kenya concluded that government ought to increase its expenditures on those items that enter private production functions as productive public inputs that enhance expansion of private investors ${ }^{e e}$ activities. Such productive government expenditure includes expenditure on physical transport and communication infrastructures, health and education facilities, buildings, plant, machinery and equipment, all of which generate positive externalities that raise private investment.

Yaw (2000) suggested that policies that address only some components of macroeconomic instability may not be enough to revive private investment. The growth of real credit to the private sector has a positive and statistically significant effect on private investment. The question of finance must therefore be addressed in order to ensure continuing participation of the private sector in investment. Private investment and public investment are found to be complementary and thus there is the need for the government to continue to develop the infrastructural base of the economy to boost the private sector.

Mohammad and Salma (2005) investigated a research study entitled the investment scenario in Bangladishproblems and prospects. They have been suggested that Investment opportunity disrupted largely by problems like bureaucracy, inadequate infrastructure, delay in implementation of policy, lack of information, operational inefficiency in institutions related to investment. Moreover, all these problems increase the investment cost of investors.

A research paper conducted by Samuel (2011) entitled Government Capital Spending and Financing and its 
Impact on Private Investment in Kenya identified that Investment in infrastructure has an insignificant positive effect on private investment in Kenya.

Pradyumna (2013) conducted a study on the impact of public investment on private investment:evidence from India. The result of this study revealed that, public infrastructure (represented by the kilometres of roads per capita) is found to have a positive effect on private investment in the short run. More than this the result concluded that public investment crowds out private investment. Infrastructures are public goods and services that go into the production process as complementary inputs for traditional factors of production such as capital, labor and entrepreneur.

The Conference Board of Canada (2013) concluded that as infrastructure projects are completed, they bolster the stock of physical capital and boost the productive capacity of the economy over the long term. There is strong evidence in the literature about the link between public capital and private sector productivity; however, the strength of the relationship is difficult to establish with certainty.

\subsubsection{Finance Related Factors}

According to a study made in North Sumatera, Indonesia, economic growth, investment credit and GDP have a positive and significant effect on private investment both in the short and long term whereas government investment, interest rates, inflation, economic crisis and international interest rate have a significant but negative effect on private investment (Nainggolan, et al, 2014)

Hailu (2013), in his study entitled with determinants of private investment in Ethiopia explained that public investment, real GDP per-capital, and external debt have significant positive long run effect on private investment whereas real GDP per-capita and external debt have significant positive contribution to private investment, while inflation has significant short negative effect on private investment in short run.

In an earlier study by Muhidin (2016) on determinants of private investment, it is found that national income, public investment and exchange rate are the critical variables affecting the performance of private investment. The other variables: interest rate, credit, inflation rate, international trade, and money supply are also slightly important in explaining the performance of private investment

Kehinde et.al. (2012) revealed that private sector output, Gross domestic product, credit to the private sector have all been significant determinants of private investment rates. They have found that if the sector lack adequate credit then there will be a reduction in the level of private investment with adverse effect on the long term productive capacity of the private sector. The introduction of a very important variable i.e. annual interest rate. Their study results suggest that interest rate is inversely related to private investment but it is significant. This is consistence with the empirical evidence that when interest rate rises, cost of borrowing increases so, there will be a decline in future profits. As a result, the stimulus to invest is discouraged. The result provide evidence that private investment in Nigeria is constrained by availability of financing, and that monetary policy, and that monetary policy, could be used to influence private investment decision. In order to attract the private investment, a country must formulate and implement suitable polices. The proper use of bank credit as a policy instrument can actually influence the level of private investment. Ajide ,(2013) also described savings, real GDP, degree of openness, real interest rates, inflation rates and governance measures are strong determining variables on private investment mobilization.

Policies like deepening financial liberalization, improve the efficiency of the commercial banking system, promote deepening of capital markets, scale up support to SME financing through partial credit guarantees, promote financial innovation, promote creation of credit bureaus etc are need to be done so as to increase business enterprises' access to credit (Fiestas and Sinha , 2011). Expected rates of return, real exchange rate, inflation although its immediate impact seems to stimulate investment, with time, the effect seems to vanish and become negative are important determinants of private investment in the short run. Credit availability allows higher levels of private investment (Acosta and Loza , 2005)

A study made by Adugna (2013) revealed that public investments in basic infrastructures and social overheads are essential for private investment in countries like Ethiopia where such basics are in serious shortage, and where private sectors do not usually dare to go for. Besides, rising real per-capita income of the peoples has crucial positive effect on private investment by way of increasing market demand for goods and services, which in turn trigger private investment.

Likewise, external debt, as long as it issued in productive investment (without creating serious debt servicing burden on the economy)has favorable effect on the private investment in countries like Ethiopia where there is serious shortage of finance. On the other hand, high and protracted inflation rate could undercut private investment by signaling macro-economic instability, and thereby weakening investors' desire and ability to invest.

Agidew, ( 2014), in his study entitled Macroeconomic determinants of domestic private investment with special reference to East African region, has outlined credit to the private sector, rate of inflation, real exchange rate among those factors which affect domestic private investment. That is credit to the private sector has stimulated the growth of domestic private investment in the region. It connects with the growth of financial 
systems which provide financing to the required investment projects. He, further explained that financial system liberalization will create suitable environment for the domestic private investments and hence stimulate domestic private investments in the region. Likewise, the rate of inflation negatively affects domestic private investment activities in the region. This indication of macroeconomic instability has a statistical significant impact on the domestic private investments. In the same way, real exchange rate movement exhibits an unfavorable effect on the development of the private sector of the economy. Real devaluation raises cost of imported capital goods where East African countries imports large volume of items for investment projects.

Fiestas and Sinha(2011) reviewed firms need to be able to access external finance to invest more. Moreover, the higher the cost of capital the lower the expected rate of return to the entrepreneur. There is a robust body of literature that shows that financial deepening, measured by the ratio of private credit to GDP, results in higher rates of growth and faster growth in the incomes of the poor, especially in the poorer countries with less well developed financial sectors.

\subsection{Conceptual framework of the study}

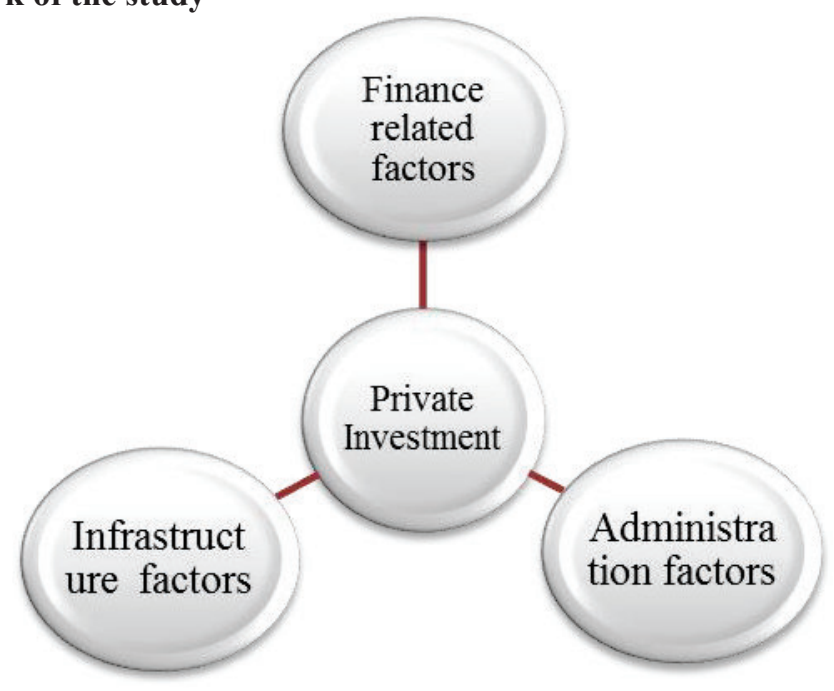

\subsection{METHODOLOGY OF THE STUDY}

\subsubsection{Research Design}

The researchers have employed descriptive type of research design by giving more emphasis on qualitative data analysis method. Qualitative research analysis has been applied to explain the challenges and opportunities of private investment in East Gojjam Zone and to obtain systematic sequence of information to get into the depth of research problems. On the other hand, quantitative research analysis has been used to provide numerical measurement and analysis of the magnitude and extent of the problem and trend of private investment in East Gojjam Zone.

\subsubsection{Sources of Data}

The researcher employed both purposive and stratified sampling techniques to select the actual sample size from the total study population. Two individuals were selected purposively from East Gojjam zone investment and trade department for interview purpose. Based on business type strata, stratified sampling techniques have been used to select sample respondents from the study population in each sector of investment.

Survey was undertaken by conducting a survey with 299 investors, using a pre-designed questionnaire. Stratified sampling technique was used to select the sampled investors in each sector. Private Investors covered by the survey have been classified into 5 strata that include service sectors, trade sectors, manufacturing sectors, construction sectors and agricultural sectors. The classification of the strata is based on the classification of investment sector of the zonal bureau of investment in East Gojjam Zone. Sample woredas were selected purposively from east Gojjam zone based on higher number of investment.

Generally, the actual sample size of any study is depending on the total population, the research budget and the available time to accomplish the study. Given these in to account, the study utilized the following sample size determining formula to set the actual sample size scientifically (Taro Yamane, 1967).

$n=\frac{N}{1+N\left(e^{2}\right)}$

Where $\mathbf{n}=$ actual sample size, $\mathbf{N}=$ total population, $\boldsymbol{e}=$ Degree of accuracy usually set at 0.05

The formula states: 


\section{$n=\frac{1165}{1+1165\left(0.05^{2}\right)}=299$}

\subsubsection{Methods of Data Analysis and Interpretation}

The process of data analysis is assisted by making use of the computer aided software available, mainly for analyzing the quantitative data. The relevant computer software [SPSS Ver. 16] has been used as a tool to manage the quantitative data. The respondents' scores is summarized and analyzed using both simple statistical techniques such as tables, charts, percentages etc. and descriptive statistics like the mean, standard deviation. Using tables, graphs and percentages as the basis of interpretation the researchers have interpreted data after analysis.

\subsection{Result and Discussion}

1.7.1. Administrative, Infrastructure and Finance Related Factors Affecting Private Investment 1.7.1.1. Administrative and Policy Related Factors Affecting Private Investment
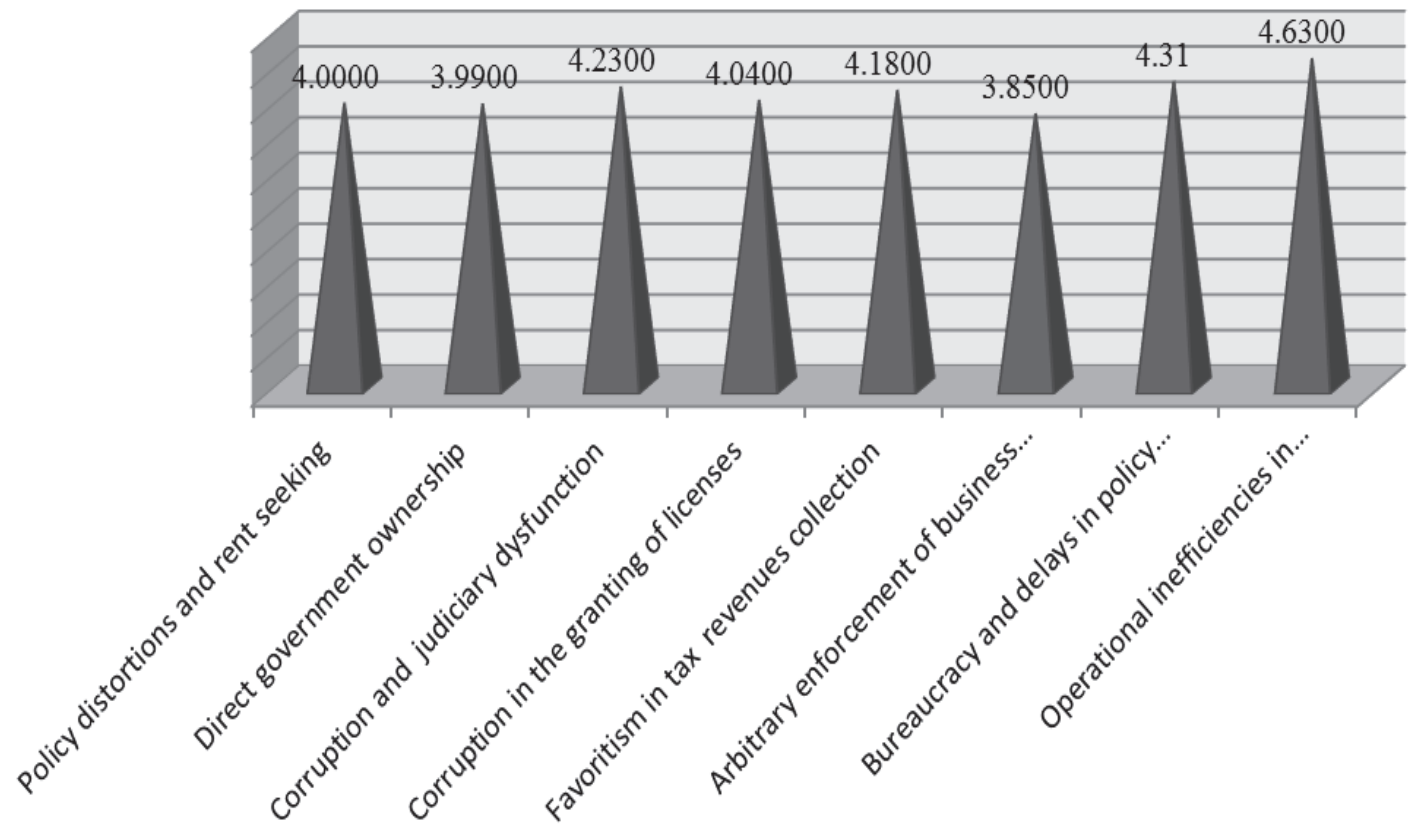

Chart 1. Administrative and Policy Related Factors

As per chart 4.1 above, administrative and policy related factors like policy distortions and rent seeking, direct government involvement in some investment areas, corruption and dysfunction of the judiciary system, malpractices in granting licenses of investment activities, favoritism in tax revenue collection, arbitrary and inappropriate enforcement of business regulations, bureaucracy and policy implementation delay have brought major hindrances on the investment activities in East Gojjam zone all having a mean score of around 4.00 and close to 4.00. This means, majority of the investors in the zone agree that the above administrative and policy related factors are their major problems for their investment activities. Among these factors, operational inefficiencies of those government institutions is considered as the main obstacle by majority of private investors in the study area having a mean value of 4.63 which close to 5 . That is they strongly agree that operational inefficiencies of some government offices which have affinity of investment activities deter significantly their investment practices. Emery (203), apparently clarifies the quality of governance directly affects the level and nature of private investment in a given country. He explained the relationship of governance to private investment is complex and is subject to many influences governance/ administrative issues like policy distortions, rent seeking, use of direct government ownership for political and patronage objectives, corruption and dysfunction of the judiciary system, corruption in the granting of investment licenses, tax collection favoritism, and others significantly affect investment in the private sector. degree of openness, previous value of inflation rates and governance indicators are the most important factors but political stability and voice and accountability indicators appear to dominate the governance indicators space as they are both negative and significantly affecting the private investment mobilization (Ajide ,2013). Likewise, unpredictable and inefficient investment climate (which could be due to reasons such as frequent changes of investment policies and requirements, inefficient bureaucracy, prolonged poor governance and rampant corruption among others), would deteriorate investors' confidence and appetite (Adugna, 2013) 


\subsubsection{Infrastructure and other Factors}

According to chart 2 below, except unavailability of working age people in the investment area, other factors which include electricity, water supply, inadequate transport and communication system, unavailability of health and educational facilities are all problems of private investment in the study area. Particularly, adequate electric energy, water supply and transportation and communication having a mean score of 4.91, 4.76, and 4.69 are considered as pillars of private investment by majority of by majority of the respondents as their mean value is close to 5.00. Access to education and health facilities have a relatively less degree of influence compared to the above variables as their mean values are close to 4:00. Unavailability of working age people is considered as a problem for private investment in the area as its mean score is close to 2:00. This means, this variable can instead be an enabling condition/ opportunity for private investment in the zone. The results of different studies substantiate our findings. Samuel (2011), highlighted Government Capital Spending and Financing and its Impact on Private Investment in Kenya identified that Investment in infrastructure has an insignificant positive effect on private investment in Kenya. public infrastructure (represented by the kilometres of roads per capita) is found to have a positive effect on private investment in the short run (Pradyumna (2013)

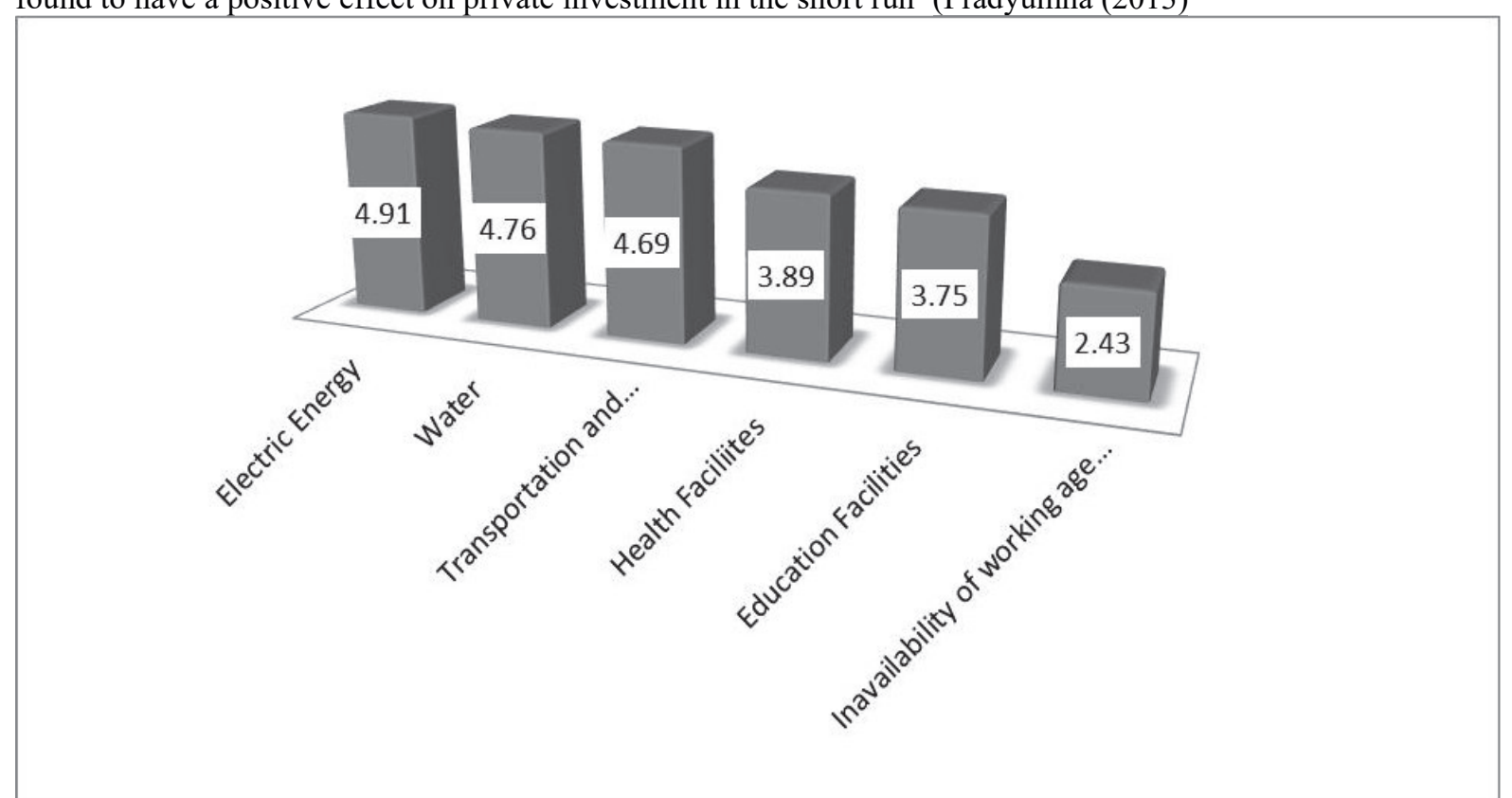

\section{Chart 2. Infrastructure and others}

\subsubsection{Finance Related Factors Affecting Private Investment}

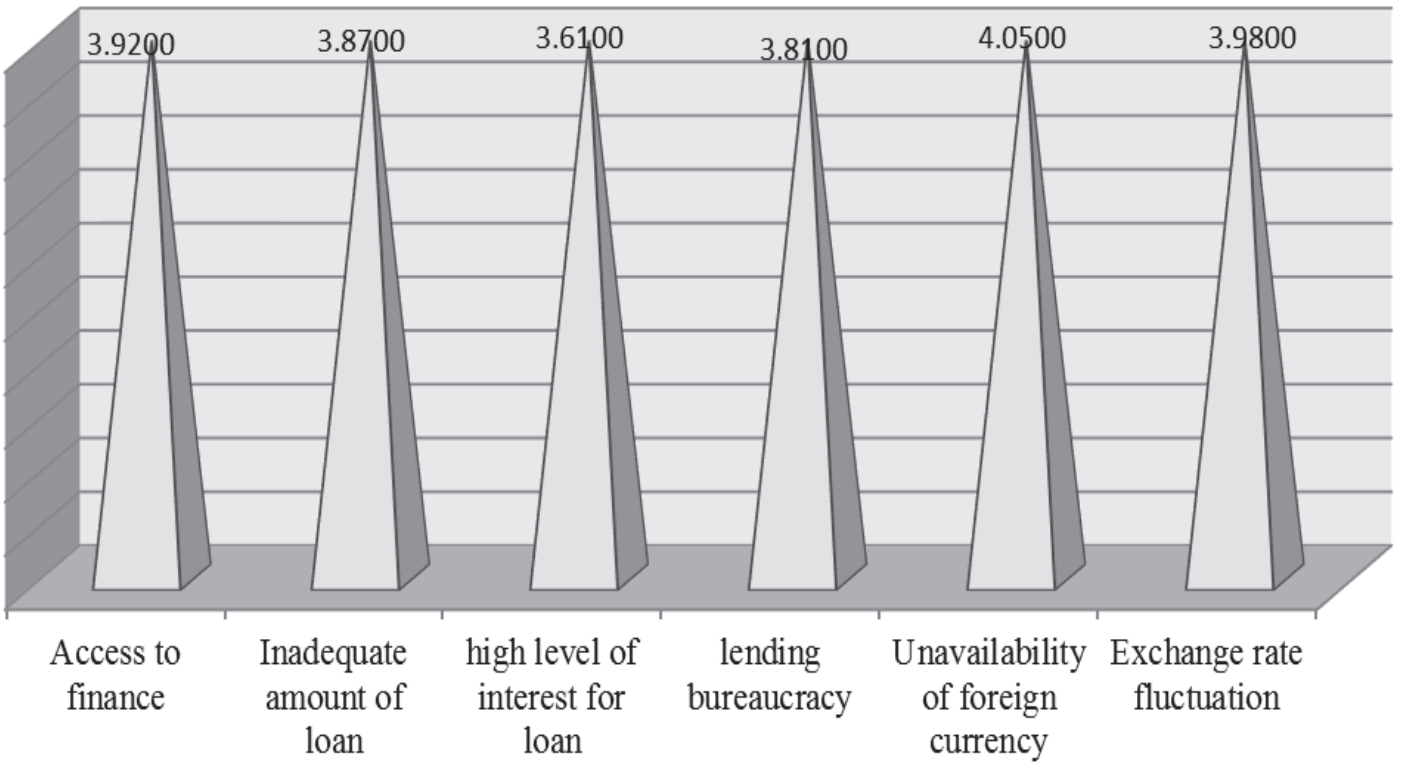

Chart:3. Finance Related Factors 
The degree of challenge investors faced with finance related factors is depicted by the above chart 3 . Though they are macro economic variables which have a nationwide effect, unavailability of foreign exchange reserves and exchange rate fluctuations are the main problems hamper their investment activities in the study area having a mean score of 4.05 and 3.98 respectively which are close to 4.00 (agree). This means that majority of the investors agree that shortage of foreign currency, particularly the USD, and fluctuations of exchange rates significantly discourages their investment. Other variables which include access to credit in formal financial institutions, inadequate amount of loan, high interest rates, and bureaucracy of lending institutions to give loan are all affecting investment practices in East Gojjam zone significantly having a mean value of $3.92,3.87,3.61$ and 3.81 which are very close to 4.00 (agree). Compared to the previous two finance related factors, they bring a lesser influence up on investors' activities in the zone. Findings of earlier studies made in different parts of the world support our findings. For instance, investment credit, interest rates, inflation have negative significant effect on private investment (Nainggolan, et al, 2014). Exchange rate, access to credit, inflation rate, money supply are among those variables affecting the performance of private investment (Muhidin 2016). Lack of adequate credit will bring a reduction in reduction in the level of private investment with adverse effect on the long term productive capacity of the private sector (Kehinde et.al. 2012))

Policies like deepening financial liberalization, improve the efficiency of the commercial banking system, promote deepening of capital markets, scale up support to SME financing through partial credit guarantees, promote financial innovation, promote creation of credit bureaus etc are need to be done so as to increase business enterprises' access to credit (Fiestas and Sinha , 2011). Acosta and Loza (2005), also highlighted expected rates of return, real exchange rate, inflation although its immediate impact seems to stimulate investment, with time, the effect seems to vanish and become negative are important determinants of private investment in the short run. Credit availability allows higher levels of private investment.

\subsection{Conclusions}

Administrative and policy related factors like policy distortions and rent seeking, direct government involvement in some investment areas, corruption and dysfunction of the judiciary system, malpractices in granting licenses of investment activities, favoritism in tax revenue collection, arbitrary and inappropriate enforcement of business regulations, bureaucracy and policy implementation delay have brought major hindrances on the investment activities in East Gojjam zone. Among these factors, operational inefficiencies of those government institutions are considered as the main obstacle by majority of private investors in the study area.

Infrastructure related factors such as Electricity energy, water, transportation and communication, health facilities, education facilities and unavailability of working age people are investigated whether they are factors or opportunities of investment. Electricity energy, water, transportation and communication, health facilities, education facilities are considered as obstacle by majority of private investors in the study area, except unavailability of working age people in the investment area which is opportunity of investment in the area.

Macro economic variables which have a nationwide effect, unavailability of foreign exchange reserves and exchange rate fluctuations are the main problems hamper their investment activities in the study area. Other variables which include access to credit in formal financial institutions, inadequate amount of loan, high interest rates, and bureaucracy of lending institutions to give loan are all affecting investment practices in East Gojjam zone significantly.

\subsection{Recommendations}

The followings are some of the recommendations given by the researchers in relation to the findings of the research.

Administrative issues like operational inefficiencies of some government offices ,policy distortions and rent seeking, direct government involvement in some investment areas, corruption and dysfunction of the judiciary system, malpractices in granting licenses of investment activities, favoritism in tax revenue collection, arbitrary and inappropriate enforcement of business regulations, bureaucracy and policy implementation delay are major problems for investment activities in East Gojjam zone. Hence, the administrative zone should have strive to bring good governance system by appointing hard working, efficient, well trained, and ethical officials who have the will and capacity to implement the government investment policies .

Underdevelopment of infrastructures particularly, water supply, electricity, transportation and communication, health and educational facilities are also other variables which influences private investment activities in the study area. Therefore, there should have to be adequate water supply, electrification and other facilities in the investment area. Specially, as electricity and transportation are the main problems, the government has to do something to curb these basic investment infrastructures. This may be solved by constructing road networks, railways to ensure an ease access to transport and make the Ethiopian Electric Corporation give a better service, if not, even privatizing the corporation might be a solution.

Other bottlenecks of private investment in East Gojjam zone are related to access to finance which basically 
comprises of getting loanable funds, amount of interest rates, inflation rates, lack of foreign currencies, the devaluation of the domestic currency in terms of the foreign currencies, etc. Therefore, it is better if the lending institutions relax their lending policies so that investors will have an ease access to finance as well as they are able to get the required amount of finance. In addition, the government has to create a stable macro economic conditions like stable foreign exchange rate, lowering the current prevailing inflation rate, adopting fair interest rate policy for bank loans, ensure adequate availability of foreign currencies and so on in the country.

\section{References}

1. Gebremeskel Awet Wedaj et al. (2015) Assessment of private investment in tigray, northern Ethiopia: challenges and opportunities in the case of manufacturing SECTORInternationalJournal of Current ResearchVol. 7, Issue, 01, pp.12210-12217.

2. Basu, et al (2002), Foreign Direct Investment in Africa - Some Case Studies. IMF Working Paper 61.

3. Hailu Adugna (2013) Determinats of private investment in Ethiopia, Journal of Economics and Sustainable Development ISSN 2222-1700 (Paper) ISSN 2222-2855 (Online) Vol.4, No.20, 2013

4. Korolev p, (2010).potential opportunities for investors, Mekelle, Ethiopia. KPMG International.

5. Majeed, M.T. and S. Khan (2008) 'The Determinants of Private Investment and the Relationship between Public and Private Investment in Pakistan', Journal of Businessand Economics

6. Morisset\& Jacques (2000), "Foreign Direct Investment in Africa: Policies Also matter." Transnational Corporation, 9(2), 107-125.

7. MuhdinMuhammedhussenBatu. Determinants of Private Investment: A Systematic Review. International Journal of Economics, Finance and Management Sciences. Vol. 4, No. 2, 2016, pp. 52-56. doi: 10.11648/j.ijefm.20160402.13

8. PinondangNainggolan,et.el, An Analysis of Determinant on Private Investment in North Sumatra Province, Indonesia, Journal of Management Research ISSN 1941-899X2015, Vol. 7, No. 1

9. Oakland Institute's (2010). Understanding land investment deals in Africa: Ethiopia.

10. Pfeffermann, G.P. and A. Madarassy (1992) 'Trends in Private Investment in DevelopingCountries': International Finance Corporation: The World bank, Washington D.C.

11. Salisu, \& Mohammed (2003), Foreign Direct Investment in Sub-Saharan Africa, The management School, Lancaster University.

12. UNCTAD (2002). Investment and innovation policy review in Ethiopia. www.oaklandinstitute.org.

13. World Bank, (2004).Opportunities and challenges for developing high-value agricultural exports in Ethiopia.

14. Kehinde .O.et al . 2012. The Determinants of Domestic Private Investment in Nigeria. IOSR Journal of Humanities and Social Science (JHSS)

15. Emery J. James . 2003. Governance, Transparency and Private Investment in Africa. Global Forum on International Investment. Johannesburg, South Africa

16. Agidew Esubalew Tadele. 2014. Determinants of Domestic Private Investment; Evidence from East Africa; International Institute of Social Studies

17. Ajide Kazeem Bello. 2013. The Role of Governance on Private Investment in Nigeria: A Preliminary Analysis, Central Bank of Nigeria Economic and Financial Review Volume 51

18. Adugna Hailu. 2013. Determinants of Private Investment in Ethiopia, Journal of Economics andSustainable Development, Vol.4, No.20.

19. Acosta, P., \& Loza, A. (2005). Short and Long Run Determinants of Private Investment inArgentina. Journal of Applied Economics, 2(8), 389-406.

20. Fiestas. I and S. Sinha (2011) 'Constraints to Private Investment in the Poorest DevelopingCountries' a Review of Literature'. Department for International Development, London UK.

21. Akhter Rahma and Sumi Farhana Rahman . 2014. Socio-Cultural Factors Influencing Entrepreneurial Activities: A case Study in Bangladesh, IOSR Journal of Business and Management, Volume 16, Issue 9.Ver. II

22. Nnabuike O..Osadebe, 2015. Socio-cultural Factors Affecting the Performance of Micro and Small Scale Enterprises in Anambra and Abia States, Nigeria.

23. Clobanu R. and Bahna M.2015.The Social, Cultural and Political Factors that Influence the Level of Mergers and Acquisitions, International Journal of Academic Research in Accounting, Finance and Management Sciences, Vol 5, No.3.

24. Kodithuwakku, D., Yasasi W., Jayawardhana, M., Muhandiramge K. \& Dulani, K., (2016) Study on the factors affecting private investments in Sri Lanka: Journal of Social Statistics 2016

25. Najeb.M.(2013)The Impact of Stock Market Performance upon Economic Growth:International Journal of Economics and Financial Issues Vol. 3, No. 4, 2013, pp.788-798

26. Jan, D. (2000) Private Investment in Developing Countries: the Effects of Commodity Shocks and Uncertainty: Centre for the Study of African Economies. 
27. Udo, N. (2013) Determinants of Private Investment in Nigeria: An Empirical Exploration: Journal of Economics and Sustainable Development, ISSN 2222-1700 (Paper) ISSN 2222-2855 Vol.7, No.11, 2016.

28. Najeb, M. (2013) The Impact of Stock Market Performance upon Economic Growth International Journal of Economics and Financial Issues Vol. 3, No. 4, 2013, pp.788-798

29. World Bank Development report (2005) Infrastructure and Financial Sector Development: ISBN 92-6402586-3 Policy Framework for Investment A Review of Good Practices C OECD 2006

30. Organization for Economic Cooperation and Development Annual Report (2006)https://www.oecd.org/newsroom/36511265.pdf

31. Grace, O., Eugenia, A. \& George, A. (2016) Does Stock Market Development Enhance Private Investment in Ghana?:International Journal of Humanities and Social Science Research, 2016, 2, 68-78

32. Peter, H. (2010) People and Places: Can They Align to BringGrowth to Africa?, center for global development essay, www.cgdev.org/content/publications/detail/1424441

33. Stephen, G., Charles, O., Nelson, W. \&Nelson W., (2014) Impact of Government Expenditure on Private Investment in Kenya: Researchjournali's Journal of Economics Vol. 2 | No. 8 August | 2014 ISSN 23478233

34. Yaw, A. (2000) Determinants of Private Investment Behavior:The African Economic Research Consortium P.O. Box 62882 Nairobi, Kenya

35. Mohammad, B. and Salma, A. (2005) The investment scenario in Bangladish-problems and prospects: Pakistan Journal of social science 3(4): 534-540:2005.

36. Samuel, o. (2011) Government Capital Spending and Financing and its Impact on Private Investment in Kenya:1964-2006: The African Economic Research ConsortiumP.O. Box 62882 - City Square Nairobi 00200, Kenya

37. Pradyumna, D. (2013) the impact of public investment on private investment:evidence from India: VIKALPA The Journal for Decision Makers 41(4) 288-307

38. Conference Board of Canada (2013) The Economic Impact of Ontario's Infrastructure Investment Program: Briefing April 2013: Conference Board research at www.e-library.ca

39. Guerin S. (2002) The Role of Geography in Financial Integration: Foreign Direct Investment. JEL classification: F36; F21

40. Trkulja, Jovana, "Geographic Factors as Determinants of Foreign Direct Investment in Eastern Europe's Transitioning Economies" (2005).Geography Honors Projects.Paper 4.

41. DeVellis, R.F. (2003). Scale development: Theory and applications (2nd edn). Thousand Oaks, California: Sage. 